\title{
Aloe vera (L.) Webb.: Natural Sources of Antioxidants - A Review
}

\author{
Marzanna Hęs $^{1} \cdot$ Krzysztof Dziedzic $^{1,2}$ (D) Danuta Górecka ${ }^{1} \cdot{\text { Anna Jędrusek-Golińska }{ }^{1} \text { • Elżbieta Gujska }}^{3}$
}

Published online: 18 June 2019

(C) The Author(s) 2019

\begin{abstract}
Many studies have proved that bioactive components of Aloe vera have an anti-inflammatory effect and support lipid and carbohydrate metabolism, helping to maintain normal sugar and cholesterol levels in blood and normal body weight. When aloe is applied externally, it accelerates the regeneration of the damaged skin. Aloe contains antioxidants, which may increase the shelf-life and nutritional value of food; therefore, it is widely used in cosmetic, pharmaceutical and food industry. An antioxidant activity was shown for leaf's skin, flowers and gel of aloe. In this work the future of $A$. vera as effective antioxidants is primarily discussed and expected trends are summarised. Furthermore, the bioactive components and the health-promoting effects of A. vera are investigated.
\end{abstract}

Keywords Natural antioxidants $\cdot$ Bioactive components $\cdot$ Antioxidative activity $\cdot$ Aloe vera

\begin{tabular}{|c|c|}
\hline \multicolumn{2}{|c|}{ Abbreviations } \\
\hline ABTS & $\begin{array}{l}\text { 2, 2-azinobis (3-ethylbenzothiazoline- } \\
6 \text {-sulfonic acid) }\end{array}$ \\
\hline BCFA & branched-chain fatty acids \\
\hline BHA & butylated hydroxyanisole \\
\hline BHT & butylated hydroxytoluene \\
\hline cAMP & $3^{\prime}, 5^{\prime}$-cyclic adenosine monophosphate \\
\hline DPPH & 2,2-diphenyl-1-picrylhydrazyl \\
\hline $\mathrm{EC}_{50}$ & $\begin{array}{l}\text { effective concentration at which the } \\
\text { absorbance is } 0.5\end{array}$ \\
\hline DTA & ethylenediaminetetraacetic acid \\
\hline FISH & fluorescence in situ hybridization \\
\hline FOS & fructooligosaccharides \\
\hline FRAP & ferric reducing antioxidant power \\
\hline HDL & high-density lipoprotein \\
\hline $\mathrm{IC}_{50}$ & inhibitory concentrations $50 \%$ of cells \\
\hline 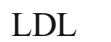 & low-density lipoprotein \\
\hline
\end{tabular}

Krzysztof Dziedzic

krzysztof.dziedzic@up.poznan.pl

1 Faculty of Food Science and Nutrition, Poznań University of Life Sciences, Wojska Polskiego 31, 60-624 Poznań, Poland

2 Department of Pediatric Gastroenterology and Metabolic Diseases, Poznan University of Medical Sciences, Szpitalna 27/33, 60-572 Poznań, Poland

3 Department of Commodity Sciences and Food Analysis, University of Warmia and Mazury in Olsztyn, Plac Cieszyński 1, 10-957 Olsztyn, Poland

$\begin{array}{ll}\text { nd } & \text { not detected } \\ \text { ORAC } & \text { oxygen radical absorbance capacity } \\ \text { qPCR } & \text { quantitative polimerase chain reaction } \\ \text { SCFA } & \text { short chain fatty acids } \\ \text { SOD } & \text { superoxide dismutase } \\ \text { TBARS } & \text { thiobarbituric acid reactive substances } \\ \text { TBHQ } & \text { tert-butylhydroquinone } \\ \text { TE } & \text { trolox equivalents } \\ \text { Wo } & \text { antioxidant efficiency }\end{array}$

\section{Introduction}

Antioxidants are substances that prevent oxidation of other compounds. To prevent food degradation due to oxidation, employment of antioxidants has become a necessity for food products, which are sensitive to this type of chemical change. Though widely used synthetic antioxidants are highly effective (e.g., BHA, BHT, TBHQ), there is growing consumer demand for natural ingredients application in processed foods. That is why new sources of natural compounds with antioxidant activity have long been sought for. This group includes those plants, which have long been in use due to their positive effect on human body, e.g., fruits, vegetables, tea, herbs and spice plants. The high content of antioxidant vitamins such as A, C, E, carotenoids and phenolic compounds in these raw materials enables them to become a source of effective and safe natural antioxidant additives that reduce lipid oxidation $[1,2]$. Food phenolics render antioxidant activity mainly due 
to their role as reducing agents, hydrogen donors, and singlet oxygen quenchers. Some phenolics also have the ability to chelate metal ions, which act as catalysts in oxidation reactions. Flavonoids are natural polyhydroxylated aromatic compounds, that are widely distributed in plants, which have the ability to scavenge free radicals, including hydroxyl, peroxyl, and superoxide radicals and can form complexes with catalytic metal ions rendering them inactive. It has been found that flavonoids can inhibit lipoxygenase and cyclooxygenase enzymes, responsible for development of oxidative rancidity in foods [3]. Aloe is widely used in the cosmetic, pharmaceutical industries and in the food industry, because it contains antioxidants, which may increase the shelf life and nutritional value of food.

\section{Classification of Antioxidants}

Antioxidants are compounds that inhibit or delay onset of oxidation and may be classified as natural or synthetic [1]. The different classes of antioxidants are shown in Table 1.

Synthetic antioxidants may cause adverse effects in humans, without any additional nutritional benefits. Due to issues of health safety surrounding food and the growing popularity of food free from synthetic additives, new sources of natural compounds with antioxidant activity have long been sought. Numerous studies confirm the high levels of effectiveness of some plant materials in the reduction of oxidative lipid rancidity. This group includes those plants which have long been used by humans due to their positive effect on the organism $-e . g$. , tea, coffee, aloe, herbs and spice plants [4, 5]. The high content of active compounds in these raw materials enables them to become a source of effective and safe natural food additives, hence it seems particularly important to search for appropriate forms of their application and an assessment of their effectiveness in differently processed products. These antioxidative additives, due to long tradition of safe consumption and the content of antioxidative substances, are not only able to reduce the amount of lipid oxidation products, but indeed exhibit this activity in an organism and shape the nutritional value of products. Based on the mechanism of action, antioxidants are categorized as primary antioxidants (radical scavengers), secondary antioxidants (peroxide scavengers), and metal deactivators (complex-forming or chelating agents) $[3,6]$. Primary, synthetic antioxidants among others are butylated hydroxyanisole (BHA), butylated hydroxytoluene (BHT), tert-butylhydroquinone (TBHQ), while natural are tocopherols, flavanoids and esters of gallic acid. The secondary antioxidants include peroxide decomposers such as thioethers, methionine, metal chelaters and glutathione peroxidase $[4,6]$.

\section{Characteristics of Aloe vera $\mathrm{L}$.}

\section{Occurrence and Botanical Characterisation}

Aloe is a tropical, drought-resistant succulent. In botany it is known as Aloe vera (L.) Webb. (Aloe barbadensis Mill.) of the Liliaceae family. Aloe vera is the most common aloe
Table 1 Different types of antioxidants $[3,6]$

\begin{tabular}{|c|c|c|}
\hline Type of antioxidants & Examples & Function \\
\hline $\begin{array}{l}\text { Free radical } \\
\text { scavengers }\end{array}$ & $\begin{array}{l}\text { Synthetic antioxidatns: } \\
\text { BHA (Butylated hydroxyanisole) } \\
\text { BHT (Butylated hydroxytoluene) } \\
\text { TBHQ (tert-Butylhydroquinone) } \\
\text { Propyl gallate } \\
\text { Natural antioxidants: } \\
\text { Tocopherols } \\
\text { Aromatic amines } \\
\text { Phenolic antioxidants } \\
\quad \text { (extracts from aloe, spices and herbs) }\end{array}$ & $\begin{array}{l}\text { Block of the radicals by donating } \\
\text { a hydrogen atoms }\end{array}$ \\
\hline $\begin{array}{l}\text { Oxygen scavengers } \\
\text { and reducing agents }\end{array}$ & $\begin{array}{l}\text { Ascorbic acid } \\
\text { Erythorbic acid } \\
\text { Ascorbates } \\
\text { Sulphites, bisulphites } \\
\text { Ascorbic palmitate } \\
\text { Amino acids }\end{array}$ & React with oxygen \\
\hline Chelating agents & $\begin{array}{l}\text { Citric acid } \\
\text { EDTA (Ethylenediaminetetraacetic acid) } \\
\text { Phosphates }\end{array}$ & $\begin{array}{l}\text { Chelate metal ions in their structure in } \\
\text { the form of stable complexes to reduce } \\
\text { the catalytic oxidation activity }\end{array}$ \\
\hline
\end{tabular}


variety. It is native to the Mediterranean region, the Arabian Peninsula, India, China and Eastern Africa. Wild forms of aloe are common in Cyprus, Malta, Sicily, the Canary Islands, and in India [7]. The biggest Aloe vera plantations can be found in the island of Barbados and in the North of the USA. Aloe has branched or unbranched shoots with greyish green sharpedged coated leaves forming a rosette. The leaves are filled with brown or yellowish milky juice that contains most bioactive compounds.

So far, more than 350 aloe species have been identified. Most of them, i.e., 42 species come from Madagascar, 12-15 species from the Arabian Peninsula, 4 from India and the other species come from other tropical countries. About 30 of them have been tested and their therapeutic properties have been confirmed, e.g., Aloe spicata, Aloe perryi Baker, Aloe socotńna, Aloe africana Miller, Aloe chinensis, Aloe perfoliata and Aloe saponaria. However, Aloe barbadensis, known as Aloe vera, Aloe ferox (bitter aloe) and Aloe aborescens (krantz aloe) are the most common species, typically used for industrial production. Aloe species do not have identical effect on the human organism. Some species are therapeutic, others are toxic or neutral [8].

Aloe vera (Aloe barbadensis Mill./Aloe vera Linn.) is the most common aloe variety. It is a short-stemmed perennial, that grows to a height of $60-100 \mathrm{~cm}$. Aloe plants have thick, green or grey and green fleshy, sword-shaped leaves. The leaf edges have triangular thorns at their edges. The flower shoot, which grows in the summer, is built from numerous, pendulous bell-shaped pink and orange flowers. When the plant sheds blossom, it gives fruit in the form of bags [8]. A flesh and pulp obtained from aloe leaves differ in composition and properties. Aloe flesh can be obtained by peeling leaves and then washing and squeezing them carefully. This procedure gives pure flesh without bitter aftertaste or strong laxative properties. Aloe flesh is light green with jelly-like consistency. It is composed of water (96\%) and dry matter (4\%), which contains protein $(6.86 \%)$, fat $(2.91 \%)$, dietary fibre $(73.35 \%)$, ascorbic acid $(0.004 \%)$ and ash $(16.88 \%)$ [9]. Apart from flesh, aloe pulp contains epidermis. It is not washed nor filtered, consequently having strong laxative properties due to the content of aloin.

\section{Bioactive Components}

Aloe contains a large amount of bioactive compounds (Table 2), such as flavonoids, terpenoids, lectins [10,11], fatty acids, anthraquinones [12], mono- and polysaccharides (pectins, hemicelluloses, glucomannan), tannins, sterols (campesterol, $\beta$-sitosterol), enzymes, salicylic acid, minerals (calcium, chromium, copper, iron, magnesium, manganese, potassium, phosphorus, sodium and zinc) and vitamins (A, $\mathrm{C}, \mathrm{E}, \beta$-carotene, B1, B2, B3, B6, choline, B12, folic acid) [13-15].

The rich chemical composition of the plant depends on a large number of factors: the type and conditions of cultivation, harvest time, climate, the position of leaves on the stem, aloe species and the method used for harvesting leaves [16]. The optimal time to harvest aloe leaves is after three years of the plant's growth, because then it has the highest content of polysaccharides $(6.55 \mathrm{~g} / \mathrm{kg})$ and flavonoids $(4.70 \mathrm{~g} / \mathrm{kg})[8,17]$.
Table 2 Chemical composition of Aloe vera $[11,55,57,58]$

\begin{tabular}{|c|c|}
\hline Compounds & Examples \\
\hline $\begin{array}{l}\text { Non essential and } \\
\text { essential amino acids }\end{array}$ & $\begin{array}{l}\text { Alanine, arginine, aspartic acid, glutamic acid, glycine, histidine, } \\
\text { hydroxyproline, isoleucine, leucine, lysine, methionine, phenylalanine, } \\
\text { proline, threonine, tyrosine, valine }\end{array}$ \\
\hline Proteins & Lectins and lectin-like substance \\
\hline $\begin{array}{l}\text { Anthraquinone and } \\
\text { anthrone }\end{array}$ & $\begin{array}{l}\text { Aloe-emodin, aloetic acid, anthranol, aloin A and B (barbaloin), } \\
\text { isobarbaloin, emodin, ester of cinnamic acid }\end{array}$ \\
\hline Enzymes & $\begin{array}{l}\text { Alkaline phosphatase, amylase, carboxypeptidase, cyclooxidase, catalase, } \\
\text { cyclooxigenase, lipase, oxidase, superoxide dismutase, } \\
\text { phosphoenolpyruvate carboxylase, glutathione peroxidase }\end{array}$ \\
\hline Hormons & Auxins and gibberellins \\
\hline Inorganic compound & $\begin{array}{l}\text { Calcium, chlorine, chromium, copper, iron, magnesium, manganese, } \\
\text { potassium, phosphorous, sodium and zinc }\end{array}$ \\
\hline Saccharides & Mannose, glucose, rhamnose \\
\hline Carbohydrate & $\begin{array}{l}\text { Pure mannan, acetylated mannan, acetylated glucomannan, glucogalactomannan, } \\
\text { galactogalacturan, arabinogalactan, cellulose, pectic substance, xylan }\end{array}$ \\
\hline Vitamines & B1, B2, B6, B12, C, $\beta$-carotene, folic acid, choline, $\alpha$-tocopherol \\
\hline Lipids & $\begin{array}{l}\text { Arachidonic acid, } \gamma \text {-linolenic acid, sterols (campesterol, cholesterol, } \beta \text {-sitosterol,), } \\
\text { triglycerides, triterpenoid, gobberellins }\end{array}$ \\
\hline Other compounds & Lignin, potassium sorbate, salicylic acid, uric acid \\
\hline
\end{tabular}




\section{Polysaccharides}

There can be different forms of polysaccharides in aloe. Their content depends on the age of the plant (Table 2). Aloe contains a soluble fibre fraction, i.e., glucomannan and a hemicellulose component that binds to fibroblast receptors in the cell walls of some plants, enhancing their proliferation. Thus, it accelerates the healing of wounds. Aloe also contains lignins, which aid the absorption of its components through the skin. In consequence, more collagen is produced when aloe is administered locally or externally [18].

Mucopolysaccharides are a special group of polysaccharides in aloe. These chemical organic compounds belong to glycosaminoglycans, which have various functions in the organism [14]. They protect the stomach and duodenum walls from the digestive effect of pepsin. They activate the protective barrier of the mucosa through the stimulation of mucus secretion and reduce susceptibility to allergies and irritations. They have positive influence on the flow of blood and lymph, in consequence preventing the formation of cellulite. Mucopolysaccharides moisturise the skin by water retention $[14,19]$. Hyaluronic acid, heparin and acemannan are the main mucopolysaccharides found in aloe, however among them acemannan is the most abundant. It has a long carbon chain, which is mainly composed of uronic acids and amino sugars. Acemannan has bactericidal, virucidal and fungicidal properties. It is also responsible for the immune reactions of the organism and one of the strongest immunomodulators of plant origin. Acemannan activates macrophages that bind and destroy microorganisms. It accumulates in cell membranes, where it makes a specific protective barrier and consequently tightens cell walls. As a result, it inhibits the absorption of toxins from the intestine into the cardiovascular system. It also aids the regeneration of natural bacterial flora. This polysaccharide ensures the normal flow of blood and lymph and gas exchange in the alveoli. It maintains the optimal moisture in cartilages and facilitates the absorption of nutrients and water in alimentary tract [20]. The human organism produces acemannan until the age of adolescence. Different factors such as stress reduce its content in the organism. The acemannan deficit is manifested by swellings, lymphostasis, digestion problems, joint and nerve root pains and various infections. It is also manifested by typical symptoms of poisoning and hypoxia [20]. Therefore, aloe consumption is a method of acemannan supplementation to improve the functioning of the organism.

\section{Glycoproteins}

Glycoproteins are natural polymers that combine proteins, carbohydrates and 16 amino acids. There are considerable amounts of glutamic and aspartic acids [21]. Glycoproteins are responsible for the identification of antibodies and prevent the breakdown of peptide bonds (proteolysis).

\section{Lectins}

Lectins (aloctin A and B) are a group of glycoproteins, which is characteristic of aloe. They differ in the connection between oligosaccharide groups and the polypeptide chain. Aloctin A connects them with the O-glycosidic bond through serine or threonine rest, but aloctin B connects them with the $\mathrm{N}$ glycosidic bond through asparagine rest. Lectins mainly play the mitogenic and immunochemical role. This means that they stimulate cell divisions and affect the growth of the number of B- and T-lymphocytes. The mechanism of action is based on the activation of cell blastic transformation, where the cell transformation from phase G0 (resting phase) to phase G1 (interphase) or synthesis is induced. Mitotic divisions are stimulated in consecutive processes [8].

Aloctins destroy cancer cells. They agglutinate carcinogenic cells by binding the polysaccharide fragments of their membranes with the active centre of aloctin [22].

\section{Anthraquinones}

Anthraquinones are anthracene derivatives of the quinone group. They are mostly known as components of strong or mild laxatives. According to recent reports, new origindependent properties of anthraquinones were discovered. They were proved to exhibit antioxidative, antiviral and cytotoxic effect on squamous cell lung cancer as well as bacteriostatic effect on Streptococcus viridans. There are also investigations to confirm the health-beneficial effect of anthraquinones on patients with malaria as well as viral and fungal infections. In most studies, experiments are at the stage of assessment of the functional properties of anthraquinones [23]. Aloe-emodin and aloin are the main anthraquinones in aloe [24]. Aloe-emodin is a compound with the primary alcohol group, mainly found in aloe juice. It is offered commercially as a powder and it is mostly a laxative. After consumption, anthra-compounds are partially absorbed in the small intestine, whereas glycoside bonds reach the large intestine, where they are hydrolysed into aglycones. Oxidation and reduction also take place. In consequence, anthranol and anthrones are produced directly irritating the intestinal mucosa. There is increased secretion from the large intestine, peristalsis is stimulated and water absorption in the intestine is inhibited. Aloe-emodin also exhibits the antioxidative effect. It has been confirmed to inhibit the oxidation of linolenic acid by $78 \%$. Its effect is caused by very strong reducing properties and the capacity to scavenge hydroxyl free radicals [25]. It is also cytotoxic to $\mathrm{CH} 27$ strain cells of squamous cell lung cancer in humans. The mechanism of action is based on increased activity of cytochrome $\mathrm{C}$, which is a transporter in 
mitochondria. It migrates to the cytoplasmic space and binds with adaptor proteins that become active only after association with another substance. It activates caspase enzymes, which cause cell apoptosis.

Aloin (barbaloin) is another representative of anthraquinones. It is aloe emodin anthrone C-glucoside, exhibiting very similar properties to aloe-emodin. Both substances are mainly laxatives. Apart from that, aloin inhibits lipid peroxidation in the cerebral cortex by inactivation of Fe(II)-dependent ascorbate.

\section{Enzymes}

Aloe contains numerous enzymes such as: alkaline phosphatase, amylase, bradykinase, catalase, lipase, protease, creatine phosphokinase, carboxypeptidase, cellulase, and oxidase [8]. Superoxide dismutase is the most important and active enzyme found in aloe [19].

\section{Phenolic Compounds}

There is diversified content of phenolic compounds in individual morphological parts of aloe (Table 3). The content of phenolic compounds in aloe's leaf epidermis is higher than in flowers. Leaves contain the most catechin $(95.0 \mathrm{mg} / 100 \mathrm{~g})$, whereas flowers contain most genistic acids $(101.0 \mathrm{mg} / 100 \mathrm{~g})$ [26].

The total content of phenolic compounds in aloe's leaf epidermis and flowers amounts to 307.5 and $274.5 \mathrm{mg}$ per $100 \mathrm{~g}$ of lyophilised material, respectively [26].

\section{Antioxidant Activity}

The in vitro antioxidant activity of $A$. arborescens [27], A. ferox [28-30], Aloe greatheadii var. Davyana [31], A. harlana [32], A. saponaria [33], A. marlothii, and A. melanacantha [34] leaf extracts were reported in the literature. Sazhina et al. [35] reported that leaf extracts from 15

Table 3 The content of selected polyphenols in aloe extracts [26]

\begin{tabular}{lll}
\hline Phenolic compound & Leaf skin & Flowers \\
\hline Catechin & 95.0 & 7.6 \\
Sinapic acid & 54.0 & 15.0 \\
Quercetin & 34.4 & nd \\
Quercitrin & 23.0 & 31.9 \\
Rutin & 22.3 & 11.6 \\
Miricetin & 19.6 & 1.8 \\
Epicatechin & 16.2 & 58.0 \\
Gentisic acid & 6.0 & 101.0 \\
\hline
\end{tabular}

* mg per $100 \mathrm{~g}$ of freeze-dried aloe material

nd - not detected
Aloe species exhibited high antioxidant activity. A. ferox antioxidant capacity was determined using ORAC and FRAP analyses [28]. Authors reported that due to the FRAP analysis being an indication of the ferric ion reducing power of a compound or mixture and the ORAC analysis indicating the ability of a compound or mixture to scavenge free radicals, the various individual polyphenol components of the mixture may have stronger free radical scavenging abilities than reducing power, or vice versa, depending on their chemical structures. As a result, it can be used in alleviating symptoms or preventing oxidative stress-related diseases. Wintola and Afolyan [30] noted than the free radical scavenging activity of the methanol, acetone and ethanol extracts of Aloe ferox Mill at a concentration of $0.5 \mathrm{mg} / \mathrm{mL}$, showed higher inhibition against ABTS, hydrogen peroxide and nitric oxide radicals. Whereas, scavenging activity of the extracts against DPPH and lipid peroxidation were was observed at a concentration of 0.016 and $0.118 \mathrm{mg} / \mathrm{mL}$, respectively in comparison to BHT, gallic acid and rutin. The ferric reducing potential of the extracts was concentration dependent and significantly different from that of vitamin $\mathrm{C}$ and BHT. Aloeresins in A. ferox displayed strong antioxidant activity [36]. Also, A. ferox leaves methanol extract showed good DPPH scavenging activity [37]. The total flavonoid contents and the antioxidant capacities of $A$. greatheadii lyophilized leaf gel, as measured by ORAC, were however higher comparatively, which may be indicative of the types of polyphenols in A. greatheadii having stronger scavenging ability than ferric ion reducing potential [31] (Table 4). The DPPH radicalscavenging activities of freeze-dried whole leaf, freeze-dried leaf skin, and boiled leaf skin were 48.2, 35.0, and $61.6 \mathrm{mM}$ Trolox equivalent/g, respectively. DPPH radical-scavenging activity was increased by boiling of freeze-dried leaf skin [27]. Likewise, Ray et al. [38] observed that aloe gel and the methanol extract of aloe gel exhibited low DPPH neutralisation capacity. However, these preparations exhibited much higher metal chelation capacity than the aqueous extract of aloe. Aloe gel inhibited the generation of DPPH radical in a dose-dependent manner and its $\mathrm{IC}_{50}$ value was found to be $572.14 \mu \mathrm{g} / \mathrm{mL}$, which is defined as the concentration of substrate that causes $50 \%$ loss of the DPPH activity (colour). A lower value of $\mathrm{IC}_{50}$ indicates the greater antioxidant activity of a test substance. Aloe scavenged the ABTS in a dose dependent manner and its $\mathrm{IC}_{50}$ value was found to be $105.26 \mu \mathrm{g} / \mathrm{mL}$.

The gel resulted in inhibition of $\mathrm{NO}$ generation in vitro in a concentration-dependent manner and its $\mathrm{IC}_{50}$ value was calculated as $46.3 \mu \mathrm{g} / \mathrm{mL}$ [39]. The $\mathrm{IC}_{50}$ of the latex from the leaves of aloe in DPPH assay was found to be $14.21 \mu \mathrm{g} / \mathrm{mL}$, while that of ascorbic acid was $4.76 \mu \mathrm{g} / \mathrm{mL}$. Isolated compounds exhibited a free radical scavenging property depending on the concentration. The degradation of deoxyribose to TBARS by hydroxyl radical generated from the Fe(III)- 
Table 4 Antioxidant activity of various forms of aloe

\begin{tabular}{|c|c|c|c|}
\hline Sample & Methods & Antioxidant activity & References \\
\hline \multirow[t]{2}{*}{ Gel extract } & DPPH radical scavenging $(\%)$ & 11.93 & \multirow{6}{*}[42]{} \\
\hline & $\begin{array}{l}\text { Ferric reducing power } \\
(\mu \mathrm{M} \mathrm{Fe}(\mathrm{II}) / \mathrm{kg})\end{array}$ & 59.12 & \\
\hline \multirow[t]{2}{*}{ Ethanol extract of gel } & DPPH radical scavenging $(\%)$ & 6.56 & \\
\hline & $\begin{array}{l}\text { Ferric reducing power } \\
(\mu \mathrm{M} \mathrm{Fe}(\mathrm{II}) / \mathrm{kg})\end{array}$ & 26.51 & \\
\hline \multirow[t]{2}{*}{ Ethanol extract of skin } & DPPH radical scavenging $(\%)$ & 85.01 & \\
\hline & $\begin{array}{l}\text { Ferric reducing power } \\
(\mu \mathrm{M} \mathrm{Fe}(\mathrm{II}) / \mathrm{kg})\end{array}$ & 185.98 & \\
\hline \multirow[t]{2}{*}{ Methanol extract of skin } & DPPH radical scavenging $(\%)$ & 58.80 & \multirow[t]{4}{*}[26]{} \\
\hline & $\begin{array}{l}\text { Ferric reducing power } \\
\text { (mM of } \mathrm{Fe}(\mathrm{III}) \text { reduced to } \mathrm{Fe}(\mathrm{II}))\end{array}$ & 2.40 & \\
\hline \multirow{2}{*}{ Methanol extract of flowers } & DPPH radical scavenging $(\%)$ & 53.00 & \\
\hline & $\begin{array}{l}\text { Ferric reducing power } \\
\text { (mM of } \mathrm{Fe}(\mathrm{III}) \text { reduced to } \mathrm{Fe}(\mathrm{II}))\end{array}$ & 1.70 & \\
\hline \multirow[t]{4}{*}{ Gel } & DPPH radical scavenging $(\%)$ & 13.52 & \multirow[t]{4}{*}{ [59] } \\
\hline & Hydroxyl radical scavenging (\%) & 11.74 & \\
\hline & Superoxide radical scavenging $(\%)$ & 53.86 & \\
\hline & Metal chelating activity (\%) & 81.27 & \\
\hline \multirow[t]{4}{*}{ Methanol extract of gel } & DPPH radical scavenging $(\%)$ & 10.24 & \multirow[t]{4}{*}[38]{} \\
\hline & Hydroxyl radical scavenging (\%) & 48.01 & \\
\hline & Superoxide radical scavenging $(\%)$ & 31.72 & \\
\hline & Metal chelating activity $(\%)$ & 48.02 & \\
\hline \multirow[t]{2}{*}{ Lyophilized leaf gel } & Oxygen radical absorbance capacity ( $\mu \mathrm{M}$ of $\mathrm{TE}^{\mathrm{a}} / \mathrm{g}$ d.m.) & 59.00 & \multirow[t]{4}{*}[31]{} \\
\hline & Ferric reducing power ( $\mu \mathrm{M} / \mathrm{g}$ d.m) & 2.63 & \\
\hline \multirow[t]{2}{*}{ Aqueous ethanol leaf gel extracts } & Oxygen radical absorbance capacity ( $\mu \mathrm{M}$ of TE/g d.m.) & 83.00 & \\
\hline & Ferric reducing power ( $\mu \mathrm{M} / \mathrm{g}$ d.m) & 8.98 & \\
\hline \multirow[t]{6}{*}{ Leaf extract } & DPPH radical scavenging $\left(\mathrm{IC}_{50}{ }^{\mathrm{b}} \mathrm{mg} / \mathrm{mL}\right)$ & $\begin{array}{l}\text { Methanol }(0.086)>\text { ethanol }(0.288)=\text { acetone } \\
\quad(0.288)>\text { aqueous extract }(0.517)\end{array}$ & \multirow[t]{6}{*}[30]{} \\
\hline & ABTS cationic radicals scavenging $\left(\mathrm{IC}_{50} \mathrm{mg} / \mathrm{mL}\right)$ & $\begin{array}{l}\text { Methanol }(0.02)>\text { acetone }(0.033)>\text { ethanol } \\
(0.062)>\text { aqueous extracts }(0.173)\end{array}$ & \\
\hline & Ferric reducing power (absorbance) & Ethanol $>$ acetone $>$ methanol $>$ aqueous extracts & \\
\hline & Nitric oxide scavenging $\left(\mathrm{IC}_{50} \mathrm{mg} / \mathrm{mL}\right)$ & $\begin{array}{l}\text { Methanol }(0.023)>\text { ethanol }(0.024)>\text { aqueous } \\
\quad(0.074)>\text { acetone extracts }(0.077)\end{array}$ & \\
\hline & Hydrogen peroxide scavenging $(\%)$ & Acetone $<$ ethanol $<$ methanol aqueous extract & \\
\hline & Lipid peroxidation $\left(\mathrm{TBARS}^{\mathrm{c}}\right)\left(\mathrm{IC}_{50} \mathrm{mg} / \mathrm{mL}\right)$ & $\begin{array}{l}\text { Methanol }(0.930)>\text { ethanol }(1.270)>\text { acetone } \\
\quad(1.492) \text { aqueous extract }(1.837)\end{array}$ & \\
\hline Freeze-dried whole leaf & DPPH-HPLC method radical-scavenging (mM of TE/g) & 48.20 & {$[27]$} \\
\hline Freeze-dried leaf skin & & 35.00 & \\
\hline Boiled leaf skin & & 61.60 & \\
\hline \multirow[t]{2}{*}{ Lyophilized leaf gel } & Oxygen radical absorbance capacity ( $\mu \mathrm{M}$ of TE/g d.m.) & 53.00 & \multirow[t]{4}{*}{ [28] } \\
\hline & Ferric reducing power $(\mu \mathrm{M} / \mathrm{g}$ d.m) & 4.90 & \\
\hline \multirow[t]{2}{*}{ Ethanol leaf gel extracts } & Oxygen radical absorbance capacity ( $\mu \mathrm{M}$ of TE/g d.m.) & 136.00 & \\
\hline & Ferric reducing power $(\mu \mathrm{M} / \mathrm{g}$ d.m) & 19.00 & \\
\hline \multirow[t]{2}{*}{ Methanol extract of aloe leaves } & DPPH radical scavenging $\left(\mathrm{EC}_{50}{ }^{\mathrm{d}}\right)(\mu \mathrm{g} / \mathrm{mL})$ & 10.45 & {$[29]$} \\
\hline & Ferric reducing power (absorbance) & $\sim 0.50$ & \\
\hline Latex from the leaves of aloe & DPPH radical scavenging $\left(\mathrm{IC}_{50}\right)(\mu \mathrm{g} / \mathrm{mL})$ & 14.21 & {$[32]$} \\
\hline & 2-Deoxyribose degradation assay $\left(\mathrm{IC}_{50}\right)(\mu \mathrm{g} / \mathrm{mL})$ & 17.24 & \\
\hline Ethanol extract of leaf of & DPPH radical scavenging $\left(\mathrm{IC}_{50}\right)(\mu \mathrm{g} / \mathrm{mL})$ & 73.00 & {$[33]$} \\
\hline aloe leaves & $\begin{array}{l}\text { Assay for inhibition of xanthine oxidase } \\
\text { activity }\left(\mathrm{IC}_{50}\right)(\mu \mathrm{g} / \mathrm{mL})\end{array}$ & 85.00 & \\
\hline Aloe gel & DPPH radical scavenging $\left(\mathrm{IC}_{50}\right)(\mu \mathrm{g} / \mathrm{mL})$ & 572.14 & [39] \\
\hline & ABTS cationic radicals scavenging $\left(\mathrm{IC}_{50}\right)(\mu \mathrm{g} / \mathrm{mL})$ & 105.26 & \\
\hline & Nitric oxide scavenging $\left(\mathrm{IC}_{50}\right)(\mu \mathrm{g} / \mathrm{mL})$ & 46.36 & \\
\hline Ethanol extracts of leaf Aloe & DPPH radical scavenging ( $\mu \mathrm{M}$ of TE) & 108.00 & {$[40]$} \\
\hline barbadensis & Oxygen radical absorbance capacity ( $\mu \mathrm{M}$ of TE) & 1281.00 & \\
\hline Ethanol extracts of leaf Aloe & DPPH radical scavenging ( $\mu \mathrm{M}$ of TE) & 71.00 & \\
\hline arborescens & Oxygen radical absorbance capacity ( $\mu \mathrm{M}$ of TE) & 2671.00 & \\
\hline Water extract of aloe & $\begin{array}{l}\text { DPPH radical scavenging } \\
\text { (mg of TE/g d.m.) }\end{array}$ & 8.87 & [43] \\
\hline & ABTS cationic radicals scavenging (mg of TE/g d.m.) & 0.87 & \\
\hline & $\begin{array}{l}\text { Metal chelating activity } \\
\text { (mg of EDTA } \% \text { g d.m.) }\end{array}$ & 8.76 & \\
\hline & Emulsion system $(\mathrm{Wo})^{\mathrm{f}}$ & 0.96 & \\
\hline Ethanol extract of flowers & DPPH radical scavenging & 0.25 & {$[60]$} \\
\hline
\end{tabular}


Table 4 (continued)

\begin{tabular}{|c|c|c|c|}
\hline Sample & Methods & Antioxidant activity & References \\
\hline & $\left(\mathrm{IC}_{50} \mathrm{mg} / \mathrm{mL}\right)$ & & \\
\hline & ABTS cationic radicals scavenging $\left(\mathrm{IC}_{50} \mathrm{mg} / \mathrm{mL}\right)$ & 0.30 & \\
\hline & Ferric reducing power & 2.10 & \\
\hline & $\left(\mathrm{EC}_{50} \mathrm{mg} / \mathrm{mL}\right)$ & & \\
\hline & Nitrite scavenging & 0.92 & \\
\hline & $\left(\mathrm{IC}_{50} \mathrm{mg} / \mathrm{mL}\right)$ & & \\
\hline \multirow[t]{5}{*}{ Methanol extracts of leaf } & DPPH radical scavenging $(\%)$ & $56.75-80.20$ & [44] \\
\hline & Metal chelating activity (\%) & $55.00-80.00$ & \\
\hline & Hydrogen peroxide scavenging (\%) & $58.54-81.10$ & \\
\hline & Ferric reducing power (absorbance) & $0.6-0.8$ & \\
\hline & $\beta$ carotene-linoleic assay $(\%)$ & $59.60-74.40$ & \\
\hline \multirow[t]{12}{*}{ Aloe barbadensis leaves } & Ferric reducing power (absorbance) & Extraction by shaker: & {$[45]$} \\
\hline & & $\begin{array}{l}\text { Absolute methanol (2.01), Aqueous ( } 80 \%) \text { methanol } \\
\text { (2.81), Absolute ethanol (1.56), Aqueous ( } 80 \%) \\
\text { ethanol (2.16) }\end{array}$ & \\
\hline & & Extraction by reflux: & \\
\hline & & $\begin{array}{l}\text { Absolute methanol (2.18), Aqueous ( } 80 \% \text { ) methanol } \\
\text { (2.96), Absolute ethanol (1.72), Aqueous ( } 80 \%) \\
\text { ethanol (1.88) }\end{array}$ & \\
\hline & DPPH radical scavenging $(\%)$ & Extraction by shaker: & \\
\hline & & $\begin{array}{l}\text { Absolute methanol (73.7), Aqueous (80\%) methanol } \\
\text { (80.1), Absolute ethanol (67.2), Aqueous (80\%) } \\
\text { ethanol (70.7) }\end{array}$ & \\
\hline & & Extraction by reflux: & \\
\hline & & $\begin{array}{l}\text { Absolute methanol (72.9), Aqueous (80\%) methanol } \\
\text { (77.6), Absolute ethanol (68.0), Aqueous ( } 80 \%) \\
\text { ethanol (71.9) }\end{array}$ & \\
\hline & Inhibition of linoleic acid peroxidation (\%) & Extraction by shaker: & \\
\hline & & $\begin{array}{l}\text { Absolute methanol (66.2), Aqueous (80\%) methanol } \\
\text { (68.3), Absolute ethanol (63.7), Aqueous (80\%) } \\
\text { ethanol (65.9) }\end{array}$ & \\
\hline & & Extraction by reflux: & \\
\hline & & $\begin{array}{l}\text { Absolute methanol (64.3), Aqueous (80\%) methanol } \\
\text { (67.9), Absolute ethanol (66.2), Aqueous (80\%) } \\
\text { ethanol (67.3) }\end{array}$ & \\
\hline
\end{tabular}

${ }^{\mathrm{a}} \mathrm{TE}$ - Trolox equivalents

${ }^{\mathrm{b}} \mathrm{IC}_{50}$ - The concentration at which $50 \%$ is inhibited

${ }^{\mathrm{c}}$ TBARS - Thiobarbituric acid reactive substances

${ }^{\mathrm{d}} \mathrm{EC}_{50}-$ Effective concentration at which the absorbance is 0.5

${ }^{\mathrm{e}}$ EDTA - Ethylenediaminetetraacetic acid equivalents

${ }^{\mathrm{f}}$ Wo - Antioxidant efficiency (Wo $>0$ antioxidative properties, Wo $<0$ prooxidative properties of the additive)

ascorbate-EDTA- $\mathrm{H}_{2} \mathrm{O}_{2}$ system was markedly decreased by the latex in a concentration dependent manner. Its $\mathrm{IC}_{50}$ value was found to be $17.24 \mu \mathrm{g} / \mathrm{mL}$, which was higher than that of the standard BHT $(4.63 \mu \mathrm{g} / \mathrm{mL})$ [32]. To investigate the antioxidant capacity of $A$. saponaria Haw., Yoo et al. [33] measured the antioxidant activity of an ethanol extract from the leaf of aloe using xanthine-xanthine oxidase (XO) assay. The assay was carried out at ten different concentrations ranging from 1 to $500 \mu \mathrm{g} / \mathrm{mL}$. The ethanol fraction from A. saponaria Haw. displayed significant dose-dependent inhibition. The ethanol fraction was found to have an $\mathrm{IC}_{50}$ value of $85 \mu \mathrm{g} / \mathrm{mL}$. In order to confirm the scavenging effect of A. saponaria Haw., DPPH assay was conducted and concentration-dependent DPPH radical scavenging activity. The ethanol fractions highly scavenged the radical generation with an $\mathrm{IC}_{50}$ value of $73 \mu \mathrm{g} / \mathrm{ml}$
[33]. 5-Methylchromones aloesin, aloeresin A, and aloesone, which are compounds present in A. barbadensis and A. arborescens, exhibited the most radical scavenging activity by DPPH and ORAC assays [40]. Hassanpour [41] noted than raspberry fruits treated with Aloe vera gel maintained higher levels of antioxidant capacity, total phenol, total anthocyanin and antioxidant enzymes during storage periods. Moniruzzaman et al. [42] and López et al. [26] observed that the aloe epidermis extract exhibited greater activity than aloe gel. They found that alcohol extracts of aloe epidermis exhibited greater DPPH radical-scavenging activity and greater capacity to reduce $\mathrm{Fe}$ (III) to $\mathrm{Fe}$ (II) than aloe flower extracts. The capacity of whole leaf extracts to scavenge the DPPH radical and ABTS cationic radical depended on the extractant applied. Methanol extracts were characterised by the highest activity. 
The gel extract exhibited greater radical-scavenging capacity than the whole leaf's extract. The extracts produced by means of hexane were characterised by the lowest activity (Table 4). The research conducted by Hesś et al. [43] showed diverse mechanisms of action for antioxidants in the aloe extract. The research results showed the high antioxidative potential of aloe aqueous solution in the emulsion system. The protective effect of linoleic acid was similar to the effect of BHT. The extract exhibited low iron ion fixing activity as well as the activity in fixing DPPH stable-free radicals and ABTS cationic radicals (Table 4). These differences in the activity of aloe preparations may have been caused by different methods of extraction of phenolic compounds, the solvent used for extraction and the morphological part of the plant (aloe's leaf epidermis and gel). The content of antioxidants in aloe also depends on numerous factors such as the type and conditions of cultivation, harvest time, climate, the position of leaves on the stem, aloe species and the method used for harvesting leaves $[16,44]$. Moniruzzaman et al. [42] proved that the content of flavonoids and the total amount of phenolic compounds in ethanol aloe extracts were strongly correlated with their DPPH radical scavenging capacity and ferric reducing power. The available literature does not provide many studies on the antioxidative potential of aloe in model systems, especially in emulsified fat systems and mass-fat systems.

Kumar et al. [44] observed that different agro-climatic conditions have effects on the phytochemicals, total phenolic content and antioxidant potential of the $A$. vera plant. The authors studied the crude methanolic extracts of $A$. vera from the different states of India for presence of various phytochemicals, total phenolic content and in vitro antioxidant activity. A significant positive correlation was detected between total phenolic content and antioxidant activity of different accessions. Extracts of highland and semi-arid zones possessed maximum antioxidant potential. Accessions from tropical zones showed the least antioxidant activity in all assays. Sultana et al. [45] checked for antioxidant activity of Aloe barbadensis leaf extracts obtained using four extracting solvents and two unique extraction techniques. They reported that the extracts had good DPPH scavenging properties. The ethanolic extracts of leaves of $A$. barbadensis prepared by the reflux technique showed better scavenging activity as compared with those prepared by the shaking technique. The aqueous organic solvent extracts of Aloe barbadensis exhibit greater reducing power than absolute solvents (Table 4). In an in vivo studiy, Golestan et al. [46] showed that dietary Aloe vera have adverse effects on antioxidant defense system in rainbow trout (O. mykiss). A total number of 480 O. mykiss were randomized into one control and three experimental groups where aloe was incorporated in their diet at $0.5,1$ and $2 \mathrm{~g} / \mathrm{kg}$. Trial conducted lasted eight weeks. Then biometry and blood sampling were identified. Plasma malondialdehyde, ferric reducing ability of plasma and growth index were estimated at the end of study. The results showed that Aloe vera extract did not affect growth indices. Malondialdehyde was increased in the experimental group compared to the control but ferric reducing ability of plasma showed a decrease in experimental groups $(p<0.05)$ compared to the control group. It has also been proved that in the occurrence of copper ions in the aqueous extract of Aloe vera the DNA is degraded and there is a reduction of $\mathrm{Cu}(\mathrm{II})$ to $\mathrm{Cu}$ (I) along with generation of reactive oxygen species such as superoxide anion and hydroxyl radicals in a dose-dependant manner. This observation demonstrates the pro-oxidant property in addition to its antioxidant property. Investigations of the antioxidant potential of a polysaccharide isolated from Aloe vera gel showed that it had a protective effect against dihydrochloride induced oxidative stress and cell's death in kidney epithelial cells [47]. Antioxidant compounds present in A. saponaria gel exerted antinociceptive and anti-inflammatory effects by the topical treatment of an ultraviolet B-induced sunburn model [48]. Nwajo [49] performed the treatment of diabetic rats with the aid of leaves of Aloe barbadensis $(150 \mathrm{mg} / \mathrm{kg})$ which increases the antioxidant enzymes like superoxide dismutase (SOD) activities, and significantly reduced the lipid peroxidation products. They concluded that augmented blood sugar leads to amplified oxidative stress and it was found that extract of Aloe barbadensis leaves possesses good antioxidant activities. It was also observed that there is a noteworthy rise in reduced glutathione, superoxide dismutase, catalase, glutathione peroxidase and glutathione-S-transferase in the liver and kidney of the treated rat [50]. Esteban et al. [51] has analysed the basic peroxidase in the commercially available aloe gel as well as in the Aloe vera plant and it has been found to occur in the vascular system of the internal aqueous leaf parenchyma. It was determined that peroxidase enzyme in skin surface possibly can scavenge $\mathrm{H}_{2} \mathrm{O}_{2}$. This illuminates that the Aloe vera plant has been constituted with agreeable antioxidant properties; moreover, this can serve as an evidence for taking this plant-based products further to the treatment of numerous diseases.

\section{Health-Promoting Effect and Health Safety}

The bioactive components of aloe have anti-inflammatory effect and aid the treatment of gastrointestinal diseases, i.e., inflammations, gastric, duodenal and intestinal ulcers. They aid lipid and carbohydrate metabolism, which helps to maintain normal blood sugar and cholesterol levels as well as normal body weight. Due to aloin, the daily intake of aloe juice should not exceed $30-40 \mathrm{~mL}$, because excessive consumption may not only have a strong laxative effect but also toxic effects. When aloe is applied externally, it helps to regenerate burnt or frostbitten skin [12, 13, 52, 53].

Figure 1 shows the medical use of Aloe vera plants. It should be noted that hydroxyanthracene derivatives occurring 
Fig. 1 Medicinal uses of Aloe vera plants $[45,55,56]$

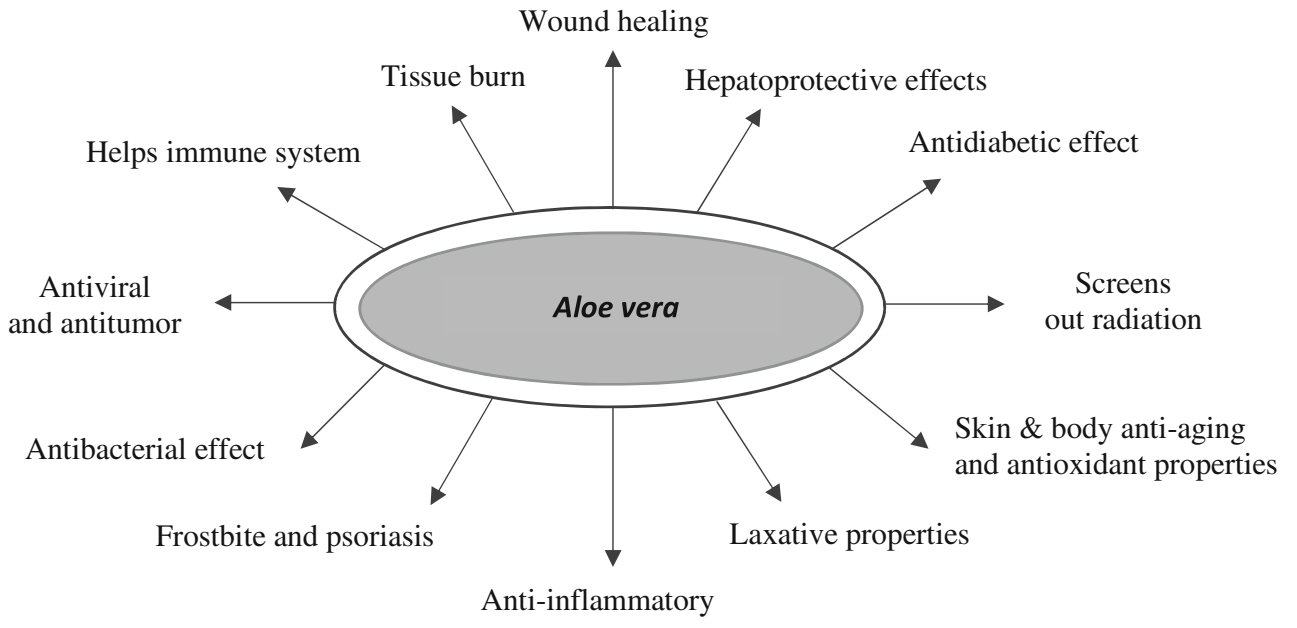

naturally in aloe have a strong purgative action, which may pose a threat to the health of humans.

As anthraquinones are commonly used as active substances in slimming and metabolism-improving preparations, they are often abused. Long-term use of anthraquinones may result in intestine inflammation, it may prolong menstrual bleeding and cause difficulties in the absorption of nutrients [24]. Due to aloin, the daily intake of aloe juice should not exceed 30$40 \mathrm{~mL}$, because excessive consumption may not only have a strong laxative effect but also toxic effects [54]. Apart from that, aloin inhibits lipid peroxidation in the cerebral cortex by inactivation of $\mathrm{Fe}$ (II)-dependent ascorbate.

\section{Conclusions}

The development of medical sciences, dietetics and nutrigenomics confirmed the correlation between the food consumed and human health. Consumers have increasingly favoured food products that contain natural ingredients due to concerns over adverse health effects of synthetic raw materials particularly some synthetic antioxidants. During the storage and processing of foods, lipids (especially those rich in polyunsaturated fatty acid residues) are oxidized. Oxidation processes are major causes of deteriorating quality. They are responsible for the degradation of aroma, taste, texture and consistency, as well as decreases of nutritive value. In addition, lipid oxidation possess health risks due to peroxides that can cause oxidation damage in living tissues. Products from lipid oxidation such as lipid peroxides and aldehydes can also induce mutagenesis and carcinogenesis. Therefore, the priority is to maximize the reduction of the oxidative metabolism of lipids. The use of plant extracts as antioxidants is gaining popularity and is widely accepted by consumers, as food additives derived from natural raw materials are known to be safe. In conclusion, polyphenols derived from aloe may exhibit a number of properties in various modelling systems.
Interests in food antioxidants will continue to increase as well as research and technology that will develop better ways of growing aloe containing higher amounts of antioxidants. Enrichment of aloe food products with polyphenols can beneficially influence their oxidative stability and thanks to additional introduction to the human organism, it may contribute to a decline in the incidence of degenerative diseases.

\section{Compliance with Ethical Standards}

Conflict of Interest None.

Open Access This article is distributed under the terms of the Creative Commons Attribution 4.0 International License (http:// creativecommons.org/licenses/by/4.0/), which permits unrestricted use, distribution, and reproduction in any medium, provided you give appropriate credit to the original author(s) and the source, provide a link to the Creative Commons license, and indicate if changes were made.

\section{References}

1. Shahidi F, Zhong Y (2010) Novel antioxidants in food quality preservation and health promotion. Eur J Lipid Sci Technol 112:930 940. https://doi.org/10.1002/ejlt.201000044

2. Duthie G, Campbell F, Bestwick C, Stephen S, Russell W (2013) Antioxidant effectiveness of vegetable powders on the lipid and protein oxidative stability of cooked Turkey meat patties: implications for health. Nutrients 5:1241-1252. https://doi.org/10.3390/ nu5041241

3. Embuscado ME (2015) Spices and herbs: natural sources of antioxidants - a mini review. J Funct Foods 18:811-819. https://doi. org/10.1016/j.jff.2015.03.005

4. Rashid F, Dhanapal K, Sravani K, Kawkabul S (2017) Potato and ginger peels: a potential new source of natural antioxidants. MOJ Food Process Technol 4:00103. https://doi.org/10.15406/mojfpt. 2017.04.00103

5. Sellami M, Slimeni O, Pokrywka A, Kuvačić G, D Hayes L, Milic M, Padulo J (2018) Herbal medicine for sports: a review. J Int Soc Sports Nutr 15:14. https://doi.org/10.1186/s12970-018-0218-y

6. Thorat I (2013) Antioxidants, their properties, uses in food products and their legal implications. Int J Food Stud 2:81-104. https://doi. org/10.7455/ijfs/2.1.2013.a7 
7. Radha MH, Laxmipriya NP (2015) Evaluation of biological properties and clinical effectiveness of Aloe vera: a systematic review. J Tradit Complement Med 5:21-26. https://doi.org/10.1016/j.jtcme. 2014.10.006

8. Benzie IFF, Wachtel-Galor S (2011) Herbal medicine: biomolecular and clinical aspects. CRC Press, Boca Raton, pp 361-382

9. Zhang Y, Bao Z, Ye X, Xie Z, He K, Mergens B, Li W, Yatcilla M, Zheng Q (2018) Chemical investigation of major constituents in Aloe vera leaves and several commercial aloe juice powders. $\mathrm{J}$ AOAC Int 101:1741-1751. https://doi.org/10.5740/jaoacint.180122

10. Boudreau MD, Beland FA (2006) An evaluation of the biological and toxicological properties of Aloe Barbadensis (miller), Aloe vera. J Environ Sci Health Part C 24:103-154. https://doi.org/10. 1080/10590500600614303

11. Harlev E, Nevo E, Lansky E, Ofir R, Bishayee A (2012) Anticancer potential of aloes: antioxidant, antiproliferative, and immunostimulatory attributes. Planta Med 78:843-852. https:// doi.org/10.1055/s-0031-1298453

12. Surjushe A, Vasani R, Saple D (2008) Aloe vera: a short review. Indian J Dermatol 53:163-166. https://doi.org/10.4103/0019-5154. 44785

13. Sahu PK, Giri DD, Singh R, et al (2013) Therapeutic and medicinal uses of Aloe vera: a review. Pharmacol Amp Pharm 4:599-610. https://doi.org/10.4236/pp.2013.48086

14. Gupta A, Rawat S (2017) Clinical importance of Aloe vera: review. Res J Top Cosmet Sci 8:30-39. https://doi.org/10.5958/2321-5844. 2017.00004.8

15. Rodrigues LLO, de Oliveira ACL, Tabrez S et al (2018) Mutagenic, antioxidant and wound healing properties of Aloe vera. $\mathrm{J}$ Ethnopharmacol 227:191-197. https://doi.org/10.1016/j.jep.2018. 08.034

16. Giannakoudakis DA, Hosseini-Bandegharaei A, Tsafrakidou P, Triantafyllidis KS, Kornaros M, Anastopoulos I (2018) Aloe vera waste biomass-based adsorbents for the removal of aquatic pollutants: a review. J Environ Manag 227:354-364. https://doi.org/10. 1016/j.jenvman.2018.08.064

17. Liu Y, Nair MG (2010) An efficient and economical MTT assay for determining the antioxidant activity of plant natural product extracts and pure compounds. J Nat Prod 73:1193-1195. https://doi.org/10. 1021/np1000945

18. Shi X-D, Yin J-Y, Huang X-J, Que ZQ, Nie SP (2018) Structural and conformational characterization of linear O-acetylglucomannan purified from gel of Aloe barbadensis Miller. Int $\mathrm{J}$ Biol Macromol 120:2373-2380. https://doi.org/10.1016/j. ijbiomac.2018.09.005

19. Gao Y, Kuok KI, Jin Y, Wang R (2018) Biomedical applications of Aloe vera. Crit Rev Food Sci Nutr 13:1-13. https://doi.org/10. 1080/10408398.2018.1496320

20. Ray A, Aswatha SM (2013) An analysis of the influence of growth periods on physical appearance, and acemannan and elemental distribution of Aloe vera L. gel. Ind Crop Prod 48:36-42. https://doi. org/10.1016/j.indcrop.2013.03.024

21. Rahmani A, Aldebasi Y, Srikar S, Khan AA, Aly SM (2015) Aloe vera: potential candidate in health management via modulation of biological activities. Pharmacogn Rev 9:120-126. https://doi.org/ 10.4103/0973-7847.162118

22. Akev N, Turkay G, Can A, Gurel A, Yildiz F, Yardibi H, Ekiz EE, Uzun H (2007) Tumour preventive effect of Aloe vera leaf pulp lectin (Aloctin I) on Ehrlich ascites tumours in mice: tumour preventive effect of Aloe vera lectin. Phytother Res 21:1070-1075. https://doi.org/10.1002/ptr.2215

23. Abdissa D, Geleta G, Bacha K, Abdissa N (2017) Phytochemical investigation of Aloe pulcherrima roots and evaluation for its antibacterial and antiplasmodial activities. PLoS One 12:e173882. https://doi.org/10.1371/journal.pone.0173882
24. Salehi B, Albayrak S, Antolak H, Kregiel D, Pawlikowska E, Sharifi-Rad M, Uprety Y, Tsouh Fokou P, Yousef Z, Amiruddin Zakaria Z, Varoni E, Sharopov F, Martins N, Iriti M, Sharifi-Rad $\mathrm{J}$ (2018) Aloe genus plants: from farm to food applications and Phytopharmacotherapy. Int J Mol Sci 19:E2843. https://doi.org/ 10.3390/ijms 19092843

25. Abdul Qadir M, Shahzadi SK, Bashir A, Munir A, Shahzad S (2017) Evaluation of phenolic compounds and antioxidant and antimicrobial activities of some common herbs. Int J Anal Chem 2017:3475738. https://doi.org/10.1155/2017/3475738

26. López A, de Tangil M, Vega-Orellana O, Ramírez A, Rico M (2013) Phenolic constituents, antioxidant and preliminary antimycoplasmic activities of leaf skin and flowers of Aloe vera (L.) Burm. f. (syn. A. barbadensis Mill.) from the Canary Islands (Spain). Molecules 18:4942-4954. https://doi.org/10.3390/ molecules18054942

27. Beppu H, Koike T, Shimpo K, Chihara T, Hoshino M, Ida C, Kuzuya H (2003) Radical-scavenging effects of Aloe arborescens Miller on prevention of pancreatic islet B-cell destruction in rats. $\mathrm{J}$ Ethnopharmacol 89:37-45. https://doi.org/10.1016/S03788741(03)00268-X

28. Loots DT, van der Westhuizen FH, Botes L (2007) Aloe ferox leaf gel phytochemical content, antioxidant capacity, and possible health benefits. J Agric Food Chem 55:6891-6896. https://doi. org/10.1021/jf071110t

29. Fawole OA, Amoo SO, Ndhlala AR, Light ME, Finnie JF, van Staden J (2010) Anti-inflammatory, anticholinesterase, antioxidant and phytochemical properties of medicinal plants used for painrelated ailments in South Africa. J Ethnopharmacol 127:235-241. https://doi.org/10.1016/j.jep.2009.11.015

30. Wintola OA, Afolayan AJ (2011) Phytochemical constituents and antioxidant activities of the whole leaf extract of Aloe ferox Mill. Pharmacogn Mag 7:325-333. https://doi.org/10.4103/0973-1296. 90414

31. Botes L, Van der Westhuizen F, Loots D (2008) Phytochemical contents and antioxidant capacities of two Aloe greatheadii var. davyana extracts. Molecules 13:2169-2180. https://doi.org/10. 3390/molecules13092169

32. Asamenew G, Bisrat D, Mazumder A, Asres K (2011) In vitro antimicrobial and antioxidant activities of Anthrone and Chromone from the latex of Aloe harlana Reynolds. Phytother Res 25:1756-1760. https://doi.org/10.1002/ptr.3482

33. Yoo EA, Kim SD, Lee WM, Park HJ, Kim SK, Cho JY, Min W, Rhee MH (2008) Evaluation of antioxidant, antinociceptive, and anti-inflammatory activities of ethanol extracts from Aloe saponaria Haw. Phytother Res 22:1389-1395. https://doi.org/10. $1002 /$ ptr. 2514

34. Cardarelli M, Rouphael Y, Pellizzoni M, Colla G, Lucini L (2017) Profile of bioactive secondary metabolites and antioxidant capacity of leaf exudates from eighteen Aloe species. Ind Crop Prod 108:44 51. https://doi.org/10.1016/j.indcrop.2017.06.017

35. Sazhina NN, Lapshin PV, Zagoskina NV, Misin VM (2016) Comparative study of antioxidant properties of extracts of various Aloe species. Russ J Bioorganic Chem 42:735-740. https://doi.org/ 10.1134/S106816201607013X

36. Jones K, Hughes J, Hong M, Jia Q, Orndorff S (2002) Modulation of melanogenesis by aloesin: a competitive inhibitor of tyrosinase. Pigment Cell Res 15:335-340. https://doi.org/10.1034/j.16000749.2002.02014.x

37. Frum Y, Viljoen AM (2006) In vitro 5-lipoxygenase and antioxidant activities of south African medicinal plants commonly used topically for skin diseases. Skin Pharmacol Physiol 19:329-335. https://doi.org/10.1159/000095253

38. Ray A, Gupta SD, Ghosh S (2013) Evaluation of anti-oxidative activity and UV absorption potential of the extracts of Aloe vera 
L. gel from different growth periods of plants. Ind Crop Prod 49: 712-719. https://doi.org/10.1016/j.indcrop.2013.06.008

39. Saini DK, Saini MR (2011) Evaluation of radioprotective efficacy and possible mechanism of action of Aloe gel. Environ Toxicol Pharmacol 31:427-435. https://doi.org/10.1016/j.etap.2011.02.004

40. Lucini L, Pellizzoni M, Pellegrino R, Molinari GP, Colla G (2015) Phytochemical constituents and in vitro radical scavenging activity of different Aloe species. Food Chem 170:501-507. https://doi.org/ 10.1016/j.foodchem.2014.08.034

41. Hassanpour H (2015) Effect of Aloe vera gel coating on antioxidant capacity, antioxidant enzyme activities and decay in raspberry fruit. LWT - Food Sci Technol 60:495-501. https://doi.org/10.1016/j. lwt.2014.07.049

42. Moniruzzaman M, Rokeya B, Ahmed S, Bhowmik A, Khalil M, Gan S (2012) In vitro antioxidant effects of Aloe barbadensis Miller extracts and the potential role of these extracts as antidiabetic and antilipidemic agents on Streptozotocin-induced type 2 diabetic model rats. Molecules 17:12851-12867. https://doi.org/10.3390/ molecules 171112851

43. Heś M, Dziedzic K, Thanh-Blicharz JL et al (2016) Antioxidant activity of true aloe (Aloe vera) extract in model systems. Nauka Przyr Technol 10. https://doi.org/10.17306/J.NPT.2016.4.53

44. Kumar S, Yadav A, Yadav M, Yadav JP (2017) Effect of climate change on phytochemical diversity, total phenolic content and in vitro antioxidant activity of Aloe vera (L.) Burm.f. BMC Res Notes 10:60. https://doi.org/10.1186/s13104-017-2385-3

45. Sultana B, Anwar F, Ashraf M (2009) Effect of extraction solvent/ technique on the antioxidant activity of selected medicinal plant extracts. Molecules 14:2167-2180. https://doi.org/10.3390/ molecules14062167

46. Golestan G, Salati AP, Keyvanshokooh S et al (2015) Effect of dietary Aloe vera on growth and lipid peroxidation indices in rainbow trout (Oncorhynchus mykiss). Vet Res Forum Int Q J 6:63-67

47. Kang M-C, Kim SY, Kim YT, Kim EA, Lee SH, Ko SC, Wijesinghe WAJP, Samarakoon KW, Kim YS, Cho JH, Jang HS, Jeon YJ (2014) In vitro and in vivo antioxidant activities of polysaccharide purified from aloe vera (Aloe barbadensis) gel. Carbohydr Polym 99:365-371. https://doi.org/10.1016/j.carbpol. 2013.07.091

48. Silva MA, Trevisan G, Hoffmeister C, Rossato MF, Boligon AA, Walker CIB, Klafke JZ, Oliveira SM, Silva CR, Athayde ML, Ferreira J (2014) Anti-inflammatory and antioxidant effects of Aloe saponaria Haw in a model of UVB-induced paw sunburn in rats. J Photochem Photobiol B 133:47-54. https://doi.org/10.1016/ j.jphotobiol.2014.02.019
49. Nwajo H (2010) Antioxidant activity of the exudate from Aloe barbadensis leaves in diabetic rats. Biokemistri 18:77-81. https:// doi.org/10.4314/biokem.v18i2.56395

50. Rajasekaran S, Sivagnanam K, Ravi K, Subramanian S (2004) Hypoglycemic effect of Aloe vera gel on streptozotocin-induced diabetes in experimental rats. J Med Food 7:61-66. https://doi. org $110.1089 / 109662004322984725$

51. Esteban A, Zapata JM, Casano L, Martín M, Sabater* B (2000) Peroxidase activity in Aloe barbadensis commercial gel: probable role in skin protection. Planta Med 66:724-727. https://doi.org/10. 1055/s-2000-9876

52. Nejatzadeh-Barandozi F (2013) Antibacterial activities and antioxidant capacity of Aloe vera. Org Med Chem Lett 3:5. https://doi. org/10.1186/2191-2858-3-5

53. Hashemi SA, Madani SA, Abediankenari S (2015) The review on properties of Aloe vera in healing of cutaneous wounds. Biomed Res Int 2015:1-6. https://doi.org/10.1155/2015/714216

54. del V-LCF, Trejo-Jasso C, Huerta-Cruz JC et al (2018) Efficacy and safety of a fixed-dose combination of D-norpseudoephedrine, triiodothyronine, atropine, aloin, and diazepam in obese patients. Int J Clin Pharmacol Ther 56:531-538. https://doi.org/10.5414/ CP203292

55. Raksha B (2014) Bioactive compounds and medicinal properties of Aloe vera L.: an update. J Plant Sci 2:102-107. https://doi.org/10. 11648/j.jps.20140203.11

56. Sánchez-Machado DI, López-Cervantes J, Sendón R, SanchesSilva A (2017) Aloe vera: ancient knowledge with new frontiers. Trends Food Sci Technol 61:94-102. https://doi.org/10.1016/j.tifs. 2016.12.005

57. Jasso de Rodríguez D, Hernández-Castillo D, Rodríguez-García R, Angulo-Sánchez JL (2005) Antifungal activity in vitro of Aloe vera pulp and liquid fraction against plant pathogenic fungi. Ind Crop Prod 21:81-87. https://doi.org/10.1016/j.indcrop.2004.01.002

58. Nadal U, Bhardwaj R 1 (2012) Aloe vera for human nutrition, health and cosmetic use - a review. Int Reseach J Plant Sci 3:38-46. ISSN: 2141-5447

59. Ray A, Gupta SD (2013) A panoptic study of antioxidant potential of foliar gel at different harvesting regiments of Aloe vera L. Ind Crop Prod 21:130-137.ISSN:0926-6690

60. Debnath T, Ghosh M, Lee YM, Nath NCD, Lee KG, Lim BO (2018) Identification of phenolic constituents and antioxidant activity of Aloe barbadensis flower extracts. Food Agric Immunol 29: 27-38. https://doi.org/10.1080/09540105.2017.1358254

Publisher's Note Springer Nature remains neutral with regard to jurisdictional claims in published maps and institutional affiliations. 